\title{
Innovative Ideological Education Operation Mechanism of Political Education of Higher Vocational Students
}

\author{
Qixin Gao \\ Hunan Vocational College of Modern Logistics, Changsha 410001, China \\ 455385116@qq.com
}

\begin{abstract}
Ideological and political education is the key point and difficult point in work of higher vocational school. The practice education operation mechanism has great and long-term significance for the ideological and political education in higher vocational school. On the basis of the analysis of the domestic practice education background, this paper objectively explains the specific content and requirements of the practice education theory and operation mechanism, and reasonably puts forward the way of higher vocational students' practice education operation mechanism of ideological and political education.
\end{abstract}

Keywords: higher vocational students; ideological and political education; practical education.

\section{Introduction}

In recent years, as the higher vocational education continuously develop and the number of higher vocational students increases sharply, the ideological and political education of higher vocational students has gradually been upgraded to an important target level by higher vocational education, and it has also become a major challenge to train socialist successors with Chinese characteristics. On December 7, 2016, General Secretary Xi Jinping emphasized the fundamental problem of the relationship of ideological and political work in colleges and universities, what kind of people are trained in and universities, how to train people and train people for who in the ideological and political work conference of colleges and universities throughout the country. At this stage, there are some problems to be solved in the ideological and political education of higher vocational schools, especially in the aspect of practice education, which should be improved and changed. The author believes that China's current higher vocational school should be based on the practical theoretical basis of Marxism in long-term exploration, integrate the goal of "practical education" into the ideological and political education of higher vocational students, establish and improve the operational mechanism of higher education students' ideological and political education practice.

\section{Practice Education Theory and Operation Mechanism Explanation}

The practice education is the education type and education mode based on the theoretical knowledge, indirect experience, operational skills and practical ability of the higher vocational students, through the combination of the students' practice education and self-education, and finally enters practice. The practice education operation mechanism is aimed at carry out and set up a variety of comprehensive, practical and guiding practice activities which have a good promotion effect on students' growth and talent training, and is closely related to higher vocational students. One dynamic and all-round practical education operation mechanism is established, its key is to emphasize that the educated students participate in various practices in person, play a necessary guiding role in their internal and behavior, so that they can grow up in continuous practice, correct their own social outlook and value, develop good self-reliance and other good characters, and become comprehensive talents useful for national society. Practice education should be the guiding goal of ideological and political education, the implementation of ideological and political education in higher vocational schools is of great significance to the implementation of practical education, the guarantee of talent training goal in higher vocational schools and the embodiment of their own educational characteristics. 


\section{Background and Reasons for Realization of Practice Education Operation Mechanism in Ideological and Political Education}

\subsection{Affirmation and Support of the Party, the State and the Government for the Practice Education}

The state and the government attach great importance to the practice education work in colleges and universities in our country, and affirm the guiding role of practice education as the goal of ideological and political work. In 2012, China's " Opinions of the ministry of education and other departments on further strengthening the practice education in colleges and universities" specifically puts forward: "further strengthen the practice education in colleges and universities, continuously enhance the social responsibility of students serving the country and the people, Innovative spirit of exploration and the practice ability to solve problem, it has an irreplaceable important role." It can be seen from the above that realizing the practice education in ideological and political education, exploring the diversification and feasibility path of students' ideological and political education, it is of great value and significance.

\subsection{Practice Education in Ideological and Political Education is the Need of the Development of Marxist Theory}

For a long time, the traditional education mode separates the theory and practice, ignores the unity between the theory and practice which are emphasized in Marxism, and the ideological and political education is lack of the proper practice link. Marxism mentioned that the theory originated from practice is not only the scientific and systematic summary of practical experience, but also the rational reflection and active transcendence of practice experience and previous theories. As far as the contemporary ideological and political education is concerned, strengthening the practice education work of ideological and political education is not only the respect and important guarantee for the educational activities with knowledge and practice, but also the inevitable demand and development needs for the relationship between theory and practice explained in Marxist theory.

\subsection{Practice Education in Ideological and Political Education is the Need of Curriculum Reform}

For a long time, most of the higher vocational colleges are limited by the traditional ideological and political education curriculum, the teaching process is too mechanized and systematic, and students have been in a passive and simple state to receive knowledge. This kind of state and thought, together with the practice conditions of many colleges and universities and the deficiency of their own level, which causes the ideological and political education to cannot produce good results. Therefore, under the press of this teaching mode with bad form and effect, ideological and political education must reform the traditional teaching mode and method, actively adapt to the new needs and forms, and create new education methods, practice education is also the need under the background of curriculum reform, so that students can become active participants in learning knowledge.

\subsection{Practice Education in Ideological and Political Education is the Choice to Conform to Educational Development Law}

From the former education to the present education, the ideological and political education of higher vocational schools must conform to the educational development law in order to carry out effectively and advantageously. Education is a comprehensive unity of teaching and learning knowledge, and a social activity among people. As the traditional education mode has gradually not adapted to the needs of the times, the implementation of practice education mechanism in ideological and political education is an inevitable choice to comply with educational development law. There are several reasons for this: first of all, the main body of practice education is human, what we pay attention to is the social practice activities that human participate in in the society, master the necessary social life experience and social survival knowledge, and improve own comprehensive quality, this is very conform to the law of human socialization, and it is an effective education means 
in line with the law of human socialization. Moreover, the improvement of individual social ability and the standardization of social behavior can also achieve the purpose of better maintaining social order and creating a good social atmosphere. Therefore, practice education is the best choice, whether from the subjective concept of individual growth and maturity or from the objective needs of social development.

\subsection{Practice Education in Ideological and Political Education is Need to Adapt to the Educational Object}

The practice education operation mechanism in ideological and political education is an effective conclusion after comprehensively consider special effect of educational object. The educational object of ideological and political education in higher vocational schools is college students; they are different from other groups of college students, they not only have the general characteristics of young college students' vitality and passion, strong self-awareness, and dare to do what they want, but also have high vocational students' poor learning attitude and habits, low learning enthusiasm, low selfcontrol ability and independent learning ability, and lack of interest in professional and theoretical knowledge. Therefore, in allusion to such special groups, we must implement the practice education operation system according to their characteristics, make them actively participate in practical activities, accept the ideological and political transformation from practice, improve their initiative and enthusiasm for learning and practice, and achieve effective and powerful education effect.

\section{Implementation Ways of Practice Education Operation Mechanism in Ideological and Political Education}

\subsection{Establish a Complete Practice Teaching System and Effective Practice Education Guarantee Mechanism}

In order to carry out the ideological and political education work in higher vocational schools smoothly, we must rely on a stable, effective and complete practice teaching institution and system. In the training plan of professional talents in higher vocational schools and clear design and planning content of ideological and political education, we should constantly integrate the links and methods of practice education; improve the contents and evaluation system of practice education, so that the practice education can be effectively and smoothly conducted. From the aspect of system, we can improve the relevant system of practice education, for example, practice education is listed in the credit assessment, so as to promote higher vocational students to participate in practice activities to improve themselves.

Moreover, higher vocational schools should also establish an effective practice education guarantee mechanism and system. The security system can be implemented under the unified leadership of the school, the school's educational administration, academic work, ideological and political work, department and other functional departments, integrate all kinds of educational resources and methods in an all-round way, and effectively guarantee the practice education.

\subsection{Enrich the form and Contents of Practice Education}

In the process of the practice education operation mechanism in ideological and political education, the form and content of practice education is one point should be paid more attention to. In order to do a good job in the practice education work of ideological and political education, the forms of practice education should be diversified, and the contents should be as rich and comprehensive as possible. In the aspect of practice form, we can take the method combining class practice form and extracurricular practice form, make them experience different social practice experience and give full play to the role of practice teaching. 


\subsection{Improve Teaching Staff and Actively Encourage Students to Participate in Practice}

In order to do a good job of practice education in ideological and political education, higher vocational schools should strengthen the most critical implementer of practice education-strengthen teachers' team, and build a teacher team with advanced education concept, high level of practice teaching, strong practical awareness and good innovative sense. In students, the school should open up, actively encourage and guide higher vocational students to participate in practice activities, and encourage them to use their holiday time to participate in voluntary service or part-time work.

\section{Conclusion}

The implementation of practice education operation system of ideological and political in higher vocational schools conforms to the needs of the times and objective development, and it has an important guiding significance for the training of high-quality talents in higher vocational schools. Higher vocational schools should regard practice education as the goal and important contents of Ideological and political education; make efforts from all aspects to give full play to the effect of ideological and political practical education in a real sense.

\section{References}

[1]. Wang Feng. Research on the Practice Education Mechanism of Ideological and Political Education of Higher Vocational Students[J]. Ability and Wisdom, 2017, (13):67-68.

[2]. Li Huiping. Construction and Innovation of Practice Education Mode of College Students' Ideological and Political Education[J]. Education and Vocation, 2015, (26): 43-44.

[3]. Guo Yi. Educational Pathways for Ideological and Political Educational Practice of College Students from the Perspective of Their Full Participation in Associations on Campus[J]. Journal of Zhejiang Normal University (Social Sciences), 2016, 41(6):121-124. 